\title{
Certolizumab pegol in the treatment of spondyloarthritis
}

\author{
Certolizumab pegol w leczeniu spondyloartropatii
}

\author{
Mariusz Korkosz \\ Department of Internal Diseases and Gerontology, Jagiellonian University Medical College, Krakow, Poland
}

Key words: ankylosing spondylitis, TNF inhibitors, inflammatory spondyloarthropaties, certolizumab pegol.

Słowa kluczowe: zesztywniające zapalenie stawów kręgosłupa, TNF inhibitor, spondyloartropatie zapalne, certolizumab pegol.

\section{Summary}

Spondyloarthropaties (SpA) are a second common group of inflammatory rheumatic diseases after systemic connective tissue diseases. They are a frequent cause of disability. Tumor necrosis factor $\alpha$ (TNF- $\alpha$ ) plays a crucial role in the initiation and continuation of chronic inflammation in SpA patients. Therefore, in case of high disease activity, despite treatment with non-steroidal anti-inflammatory drugs and/or synthetic disease modifying antirheumatic drugs, treatment with biologics is very efficacious. Certolizumab pegol is a one of the TNF inhibitors, with proven efficacy in the treatment of active SpA. This article summarizes basic data on certolizumab pegol, and results of clinical trials applied for the drug registration for the use in the management of patients with active SpA.

\section{Classification and division of spondyloarthropaties}

The group of diseases referred to as spondyloarthropaties (SpA) is traditionally divided into five types depending on dominant extraarticular signs: ankylosing spondylitis (AS), psoriatic arthritis (PsA), reactive arthritis, arthritis secondary to non-specific inflammatory bowel diseases and undifferentiated spondyloarthropathies [1]. Research conducted in recent years has shown that the division of SpA can also be based on differences in the location of articular and extraarticular lesions. Only two forms are distinguished in this way: axial spondyloarthropathy (AxSpA), which is mainly localized in the spine, and peripheral spondyloarthropathy (PSpA), which affects primarily peripheral joints [1]. The

\section{Streszczenie}

Spondyloartropatie (SpA) stanowią drugą co do częstości występowania, po układowych chorobach tkanki łącznej, grupę zapalnych chorób reumatycznych i częstą przyczynę niepełnosprawności narządu ruchu. Kluczową rolę w inicjowaniu i podtrzymywaniu przewlekłego zapalenia w SpA odgrywa czynnik martwicy nowotworów $\alpha$ (tumor necrosis factor $\alpha$ - TNF- $\alpha$ ), dlatego w przypadku utrzymującej się wysokiej aktywności SpA, pomimo leczenia standardowego niesteroidowymi lekami przeciwzapalnymi i/lub syntetycznymi lekami modyfikującymi przebieg choroby, skuteczne jest leczenie inhibitorami TNF. Certolizumab pegol jest jednym z inhibitorów TNF, który okazał się skuteczny w leczeniu aktywnych postaci SpA. W pracy przedstawiono podstawowe dane o tym leku oraz wyniki badań będących podstawą rejestracji certolizumabu w SpA.

axial and peripheral forms differ in immunopathogenesis and response to therapy - regardless of the phenotype determined by extraarticular signs. In other words, the disease with a specific SpA phenotype, occurring in patients fulfilling the criteria of, for example, axial SpA, is underlain by similar pathogenetic mechanisms, and patients display similar response to antiinflammatory drugs and disease-modifying antirheumatic drugs (DMARDs).

The new concept for SpA division is reflected in classification criteria for axial and peripheral SpA developed and published by ASAS (Assessment of SpondyloArthritis International Society) in 2010 [2]. According to the ASAS definition, axial SpA comprises: a) non-radiographic axial SpA (nr-axSpA), in which sacroiliac joint lesions are not visible on traditional X-ray, however they may be present 
on MRI, and b) radiographic axial SpA, with radiologica signs of sacroiliitis, fulfilling the modified New York criteria for AS diagnosis [3]. Progression from the non-radiographic (nr-axSpA) to the radiographic (AS) group is a natural process, though it does not occur in all patients. The proportion of patients with disease progression has been found to be correlated with the duration of the disease: for $0-2$ years, it is $8-12 \%$, for $2-9$ years, it is $20-45 \%$ and for $\geq 10$ years, it is 36-59\% [4]. Although $n$ r-axSpA and AS are associated with different radiographic characteristics of sacroiliac joints, subjective complaints, clinical symptoms and laboratory findings are comparable. Consequently, it appears that both groups should be treated with similar drugs of proven efficacy.

\section{Role of tumor necrosis factor $\alpha$ in the interaction between the immune system and bone tissue in spondyloarthropathies}

From the viewpoint of pathophysiology and disease progression, the key aspect is the interaction between immune system cells and bone tissue. Cellular mechanisms underpinning these processes, as well as mutual links between inflammation and osteogenesis in SpA remain largely unexplained. In SpA, the interaction leads both to bone tissue damage manifested as erosions and osteoporosis, and abnormal osteogenesis manifested as the formation of new bone tissue and bone fusion in joints [5]. Effective and early SpA treatment, especially before structural changes have taken place, seems to offer the possibility of preventing damage to bone tissue and, as a result, counteracting locomotor impairment typically associated with SpA. Research conducted in recent years has also provided evidence for the possibility of effective treatment of extraarticular signs of SpA, including uveitis, psoriatic skin lesions and bowel inflammation [6] coexisting in SpA.

The key cytokine in SpA, secreted by a number of proinflammatory cells, is TNF- $\alpha$ which binds to one of two receptors: TNFRp55 or TNFRp75. The binding of TNF to the receptor causes activation of nuclear factor $\kappa \mathrm{B}(\mathrm{NF}-\kappa \mathrm{B})$ via an intracellular signal pathway. After reaching the cell nucleus, activated NF- $\kappa B$ induces the transcription of genes encoding proteins which are implicated in inflammatory responses and cell apoptosis. Specific effects of TNF activity in SpA include activation of cytokine-producing leukocytes, and activation of fibroblasts and endothelial cells increasing the expression of adhesion molecules, which facilitates, among others, the migration of leukocytes into tissues [7]. Through the activation of receptor activator of NF- $\mathrm{KB}$ ligand (RANKL), TNF increases the number of osteoclasts, speeds up their maturation and enhances their activity, leading to accelerated resorption of bone tissue. TNF has an adverse effect on osteogenesis controlled by systems of wingless proteins (Wnt) and bone morphogenetic proteins (BMP) through an increase in the expression of Dickkopf-1 (Dkk-1) protein and sclerostin [8]. In addition, TNF increases the concentration of acute-phase proteins in blood. Based on the data presented above, it appears that the inhibition of TNF activity in SpA should be one of the main goals of treatment, especially in those patients in whom the activity of the disease could not be reduced with non-steroidal anti-inflammatory drugs (NSAIDs) and/or synthetic disease-modifying antirheumatic drugs (DMARDs).

\section{Treatment of spondyloarthropathies}

First-line drugs for axial SpA are NSAIDs, and for peripheral SpA - NSAIDs, synthetic DMARDs (sulphasalazine, methotrexate, leflunomide and cyclosporine) and glucocorticosteroids (GCC) in the form of injections into joints and tendon attachments.

According to recommendations issued by ASAS and EULAR (European League Against Rheumatism), inefficacy of NSAIDs in the therapy of axial SpA, similarly to inefficacy of NSAIDs, synthetic DMARDs and topical GCC injections in peripheral SpA (e.g. peripheral form of psoriatic arthritis) justify the introduction of treatment with a TNF blocker $[9,10]$. TNF inhibitors are as yet the only group of biological DMARDs with a proven efficacy in the therapy of axial SpA. Until recently, four TNF inhibitors (adalimumab, etanercept, golimumab and infliximab) were approved in Poland for the treatment of active AS. The drugs exhibit similar efficacy in the treatment of axial symptoms (spinal pain), peripheral arthritis and enthesitis in AS [11-14]. Until lately, adalimumab was the only drug approved in Poland for the treatment of active $n r$-axSpA. Recent times have seen the publication of results of studies investigating certolizumab, another TNF inhibitor, which served as the basis for the approval of the drug for the treatment of axial SpA, i.e. AS and nr-axSpA - also with methotrexate (MTX) or not - psoriatic arthritis with involvement of peripheral joints.

\section{Certolizumab pegol}

Certolizumab pegol (CZP) is a humanized Fab fragment of the anti-human TNF antibody conjugated with a molecule of polyethylene glycol (PEG). CZP's a unique feature among TNF inhibitors is the fact that it lacks the Fc antibody fragment. This pegylated molecular structure is responsible for the prolongation of the drug's half-life to ca. 2 weeks, which makes it possible to administer subcutaneous injections on a 2-4 weekly basis. Randomized phase III studies have shown that CZP in 
combination with MTX or in monotherapy is an effective drug in the treatment of rheumatoid arthritis (RA) which has remained active in spite of therapy with synthetic DMARDs, particularly MTX [15-17]. In 2009, the USA's Food and Drug Administration (FDA) approved certolizumab pegol for the treatment of moderate and severe forms of RA in monotherapy or in combination with DMARDs. Also, the EU's European Medicines Agency (EMA) approved the drug in combination with or without MTX in patients experiencing adverse reactions or having contraindications to using MTX. Certolizumab pegol is used at a loading dose of $400 \mathrm{mg}$ subcutaneously in weeks 0, 2 and 4, and then at a maintenance dose of $200 \mathrm{mg}$ every two weeks or, after achieving clinical response, $400 \mathrm{mg}$ every four weeks [18].

\section{Pharmacodynamics of certolizumab}

Similarly to other TNF inhibitors, CZP binds to soluble and membrane TNF. The efficacy of inhibition of membrane TNF depends on the concentration of CZP just like in other monoclonal antibodies targeted against TNF [19]. The lack of the Fc fragment eliminates the possibility of antibody-dependent cell-mediated cytotoxicity (ADCC) and complement-dependent cytotoxicity (CDC) in vitro [20]. CZP does not induce apoptosis of monocytes and lymphocytes, and degranulation of neutrophils in peripheral blood in vitro [20]. As with other biological drugs, certolizumab pegol is associated with immunogenicity which seems to be reduced by the process of pegylation [21]. In phase III studies, anti-CZP antibodies have been found in $9.6 \%$ of patients with RA, $4.4 \%$ of patients with axial SpA and $11.7 \%$ of patients with PSA [6, 21]. Concomitant therapy with MTX has been shown to partially inhibit the formation of antibodies [21]. In view of divergent methods of laboratory determination of antibodies in clinical studies of different TNF inhibitors, it is difficult to compare the immunogenicity of CZP with other drugs from this class. Nevertheless, the immunogenicity of CZP seems lower than that of infliximab [22].

\section{Pharmacokinetics and metabolism of certolizumab}

Following subcutaneous administration, CZP achieves its peak serum concentration within 54-171 hours, and the mean bioavailability of the drug is $80 \%$ (76-88\%) relative to intravenous administration [21]. The binding of the antibody Fab fragment to PEG delays the elimination of the molecule from the body. As mentioned above, this prolongs the drug's serum half-life to approx. 14 days. The delayed CZP elimination stems, among other factors, from prolonged proteolysis [21].
Complete elimination of the drug from the body may take five months, however the presence of anti-CZP antibodies can result in a three-fold acceleration of the elimination process [21].

Based on data from RA studies it has been established that CZP dose does not require reduction in patients with moderate kidney failure and in patients over 65 years of age, although there have been no studies targeted specifically at these variables [21]. Studies on mice with collagen-induced arthritis have demonstrated that CZP is superior to adalimumab and infliximab in penetrating into inflammation-affected tissues, which is a likely effect of pegylation of the molecule [23].

\section{Clinical studies with certolizumab in axial spondyloarthropathy}

The basis for CZP approval for the treatment of axial SpA in 2013 was the RAPID-axSpA study, i.e. "Phase III, multicenter, randomized, double-blind, placebo-controlled study to evaluate efficacy and safety of certolizumab pegol in subjects with active axial spondyloarthritis" [24]. The trial enrolled a total of 325 patients with active axial SpA according to ASAS criteria 2010 [2], i.e. a group comprising both forms of axial SpA - AS (fulfilling the modified New York criteria) [3], and nr-axSpA. The disease was defined as active if the Bath Ankylosing Spondylitis Disease Activity Score (BASDAI) was $\geq 4$, and spinal pain was assessed as $\geq 4$ in the 10 -point NRS scale (numeric rating scale). Inclusion in the study also required the presence of objective signs of inflammation, i.e. elevated blood levels of C-reactive protein (CRP) and/ or evidence of bone marrow swelling in sacroiliac joints on an MRI scan confirming active inflammation of these joints. For patients participating in the RAPID-axSpA study it was also necessary to document inadequate efficacy of treatment with at least one NSAID. The study excluded patients who have been treated with more than one TNF inhibitor and patients who have shown primary inefficacy of a TNF inhibitor. The subjects were randomized at a ratio of $1: 1: 1$ into three groups: placebo, $200 \mathrm{mg}$ of CZP every two weeks and $400 \mathrm{mg}$ of CZP every four weeks - the CZP groups had the same loading dose, i.e. $400 \mathrm{mg}$ in weeks 0, 2 and 4 of the study.

The primary end-point of the study was a 20-percent reduction in the activity of the disease measured by the ASAS 20 index in the $12^{\text {th }}$ week of treatment. The endpoint was reached by $57.7 \%$ of patients with axial SpA treated with CZP at a dose of $200 \mathrm{mg}, 63.6 \%$ of patients receiving $400 \mathrm{mg}$ of CZP, and $38.3 \%$ of subjects in the placebo group [24]. The differences between CZP-treated groups and the placebo group were statistically significant. Similarly, other indicators of response to therapy, ASAS 40 and ASAS partial remission, were significantly 
higher in week 12 in the groups of patients treated with CZP at 200 and $400 \mathrm{mg}$ than in the placebo group.

RAPID-axSpA was the first randomized placebo-controlled trial investigating both forms of axial SpA according to ASAS classification criteria issued in 2010 [2]. The study group consisted of 325 patients including 178 (54.8\%) of patients fulfilling AS criteria and 147 patients (45.2\%) satisfying nr-axSpA criteria. Taking into consideration ASAS20, ASAS40 and ASAS partial remission scores in week 12 of the study, slightly better results were observed in the nr-axSpA group, especially in the $200 \mathrm{mg}$ dose group (ASAS $2058.7 \%$ vs. 56.9\%, ASAS 40 $47.8 \%$ vs. $40 \%$, ASAS partial remission $28.3 \%$ vs. $20 \%$ ), and in the $400 \mathrm{mg}$ group in the ASAS partial remission scores (29.4\% vs. $19.6 \%)$. The differences are attributed to a shorter duration of the disease in the nr-axSpA group. Comparing both subgroups, i.e. AS and nr-axSpA, with the placebo group with respect to all improvement criteria (ASAS20, ASAS40 and ASAS partial remission), better scores were achieved in groups treated with CZP than in the placebo group. Response rates in week 24 were higher than in week 12 . The trend was especially evident in ASAS40 which exceeded $50 \%$ in the groups treated with CZP at a dose of $200 \mathrm{mg}$ or $400 \mathrm{mg}$, whereas in week 12 it was below 50\%.

As for secondary end-points, i.e. Bath Ankylosing Spondylitis Functional Index (BASFI), Bath Ankylosing Spondylitis Metrology Index (BASMI), spinal pain, fatigue and Short Form-36 (SF-36) score, improvement indicators were significantly higher in the groups treated with CZP in weeks 12 and 24 of the trial than in the placebo group. In addition to a decrease in clinical activity, another finding was a significant reduction of inflammation in the sacroiliac joints and vertebral bodies in the CZP groups than in the placebo group, as evidenced by an MRI scan in week 12 .

A review of adverse reactions noted in the RAPIDaxSpA study did not reveal any new safety signals for CZP compared to the studies of the drug in RA. Common adverse reactions (1/10-1/100 cases) linked to CZP treatment include bacterial and viral infections, neutropenia, lymphopenia, headache (including migraine), sensory disorders, arterial hypertension, nausea, elevated blood aminotransferase activity, skin rash, itching, fever and weakness. Much less frequent are certain abnormalities in laboratory test results, i.e. increased blood alkaline phosphatase activity, prolonged blood clotting time, elevated blood uric acid concentrations and abnormal wound healing.

In 2013, the outcomes of the RAPID-axSpA study were a basis for the approval of CZP for the treatment of AS in Europe and in the USA, and for the treatment of $n r-a x S p A$ in Europe (the drug is approved for use in
Poland in both these indications). According to EMA, using CZP in nr-axSpA treatment additionally requires objective features of inflammation, i.e. increased CRP concentrations in blood and/or symptoms of sacroiliitis demonstrated by MRI in patients with incomplete response to NSAIDs or with NSAID intolerance.

A metaanalysis of 20 randomized clinical trials, published in 2014, focusing on the efficacy of five TNF inhibitors in AS and nr-axSpA indicates that the drugs, as opposed to placebo, significantly reduce the activity of the disease and improve functional performance in both forms of SpA [25]. Inclusion criteria in studies investigating certolizumab, etanercept and infliximab in nr-axSpA included, among others, symptoms of active inflammation visible on MRI or elevated CRP concentration. However, the above inclusion criteria did not apply to studies of adalimumab, particularly ABILITY-1, in which less than $50 \%$ of patients had an active inflammation confirmed by MRI or an elevated concentration of CRP. Furthermore, patients enrolled in adalimumab studies had a relatively long duration of symptoms. In the opinion of the authors, both these factors were responsible for the fact that the efficacy of adalimumab in nr-axSpA trials was lower than in studies of other TNF inhibitors [25].

\section{Clinical studies with certolizumab in psoriatic arthritis}

The basis for CZP approval for the treatment of psoriatic arthritis in 2013 was the RAPID-PSA study, i.e. "Effect of certolizumab pegol in patients with psoriatic arthritis: a 24-week results of a Phase 3, double-blind randomized placebo-controlled study (RAPID-PSA)" [26]. The study recruited 409 patients meeting the CASPAR criteria of PSA [27] and having an active form of the disease defined as the presence of at least three painful and at least three swollen joints and $\mathrm{OB} \geq 28 \mathrm{~mm} / \mathrm{h}$ or CRP above the upper normal limit $(7.9 \mathrm{mg} / \mathrm{l})$, and a documented prior inadequate response to at least one DMARD. The study also involved patients with a history of treatment with a TNF inhibitor, after a three-month wash-out period (etanercept after 28 days). Active psoriatic skin lesions or a documented history of psoriasis were required. The patients were randomized at a ratio of $1: 1: 1$ into three groups: $200 \mathrm{mg}$ of CZP every two weeks or $400 \mathrm{mg}$ of CZP every four weeks - after a loading dose of $400 \mathrm{mg}$ in weeks 0,2 or 4 - or placebo.

The primary end-point was response to treatment measured according to the American College of Rheumatology 20\% (ACR20) index in week 12, and a change in Total Sharp Score in the period from randomization to week 24. Response to treatment determined in week 12 based on the ACR20 index was significantly greater in the groups receiving $200 \mathrm{mg}$ and $400 \mathrm{mg}$ of CZP than in 
the placebo group (58\% and 51.9\% vs. 24.3\%). The higher improvement rate noted in CZP-treated groups was not linked to prior exposure to TNF antagonists.

Secondary end-points included questionnaires assessing improvement in skin symptoms, nail psoriasis, enthesitis, dactylitis and general functional performance (e.g. Health Assessment Questionnaire - Disability Index - HAQ-DI). A significant improvement in functional performance (HAQ-DI) was observed in the CZP-treated groups compared to the untreated group (-0.50 vs. -0.19$)$. A greater number of patients receiving CZP in $200 \mathrm{mg}$ and $400 \mathrm{mg}$ doses achieved a higher improvement rate in the Psoriatic Arthritis Response Criteria (PSARC) index than the placebo group in week 24 (78.3\% and $77 \%$ vs. $33.1 \%$, respectively). Also, the groups treated with CZP had a significantly better improvement with regard to skin lesions and peripheral arthritis in week 12, and in terms of nail psoriasis, enthesitis and dactylitis in week 24 [26].

RAPID-PsA did not demonstrate any new, i.e. unreported in RA studies, adverse reactions associated with CZP. A rapid elimination of complaints and symptoms of PsA - arthritis, skin lesions, enthesitis, psoriatic nail lesions and dactylitis - was often observed as early as after one week of treatment. An improvement occurred in both groups treated with CZP.

\section{Conclusions}

Tumor necrosis factor inhibitors have revolutionized the treatment of SpA patients with persistently active disease despite therapy with NSAIDs and/or synthetic DMARDs. Although there have been multiple studies investigating biological drugs other than TNF inhibitors, none of them have been approved for the treatment of SpA with the exception of ustekinumab (anti-IL-12/IL-23) which has been accepted for the therapy of PsA. A number of studies have shown TNF antagonists to be effective in the treatment of AS. Two studies, i.e. ABILITY-1 with adalimumab and RAPID-axSpA with certolizumab, have also demonstrated their efficacy in the therapy of nr-axSpA [24, 28]. Certolizumab is a TNF inhibitor which can be used over the entire spectrum of axial SpA - in AS and nr-axSpA, and based on results of the RAPID-PsA trial, also in PSA with peripheral joint involvement [24, 26]. The efficacy of TNF inhibitors in the treatment of SpA has been reflected in ASAS and EULAR recommendations advocating TNF antagonists for the management of axial SpA (AS and nr-axSpA) and PsA $[9,10]$.

It remains an open question whether an appropriately early introduction of treatment with a TNF inhibitor is capable of halting the progression of radiographic changes, both destruction (erosions, osteoporosis) and osteogenesis (syndesmophytes, bone fusion), and whether in axial SpA patients it can suppress the progression of nr-axSpA to AS.

The author wishes to thank the company UCB for access to data necessary to prepare this study.

\section{References}

1. Baeten D, Breban M, Lories R, Schett G, Sieper J. Are spondylarthritides related but distinct conditions or a single disease with a heterogeneous phenotype? Arthritis Rheum 2013; 65: 12-20.

2. Rudwaleit M, van der Heijde D, Landewe R, et al. The development of assessment of SpondyloArthritis international society classification criteria for axial spondyloarthritis (part II): Validation and final selection. Ann Rheum Dis 2009; 68: 777-783.

3. van der Linden S, Valkenburg HA, Cats A. Evaluation of diagnostic criteria for ankylosing spondylitis. A proposal for modification of the New York criteria. Arthritis Rheum 1984; 27 : 361-368.

4. Sampaio-Barros PD, Bortoluzzo AB, Conde RA, et al. Undifferentiated spondyloarthritis: A longterm followup. J Rheumatol 2010; 37: 1195-1199.

5. Alnaeeli M, Teng YT. Dendritic cells: A new player in osteoimmunology. Curr Mol Med 2009; 9: 893-910.

6. Schreiber S, Khaliq-Kareemi M, Lawrance IC, et al.; PRECISE 2 Study Investigators. Maintenance therapy with certolizumab pegol for Crohn's disease. N Engl J Med 2007; 357: 239-250.

7. FitzGerald O, Mclnnes I. Spondyloarthropathy: Disease at the crossroads of immunity. Best Pract Res Clin Rheumatol 2006; 20: 949-967.

8. Dougados M, Baeten D. Spondyloarthritis. Lancet 2011; 377: 2127-2137.

9. Gossec L, Smolen JS, Gaujoux-Viala C, et al. European league against rheumatism recommendations for the management of psoriatic arthritis with pharmacological therapies. Ann Rheum Dis 2012; 71: 4-12.

10. van der Heijde D, Sieper J, Maksymowych WP, et al. 2010 update of the international ASAS recommendations for the use of anti-TNF agents in patients with axial spondyloarthritis. Ann Rheum Dis 2011; 70: 905-908.

11. Davis JC Jr, Van Der Heijde D, Braun J, et al. Recombinant human tumor necrosis factor receptor (etanercept) for treating ankylosing spondylitis: A randomized, controlled trial. Arthritis Rheum 2003; 48: 3230-3236.

12. Inman RD, Davis JC Jr, van der Heijde D, et al. Efficacy and safety of golimumab in patients with ankylosing spondylitis: Results of a randomized, double-blind, placebo-controlled, phase III trial. Arthritis Rheum 2008; 58: 3402-3412.

13. van der Heijde D, Dijkmans B, Geusens P, et al. Efficacy and safety of infliximab in patients with ankylosing spondylitis: Results of a randomized, placebo-controlled trial (ASSERT). Arthritis Rheum 2005; 52: 582-591.

14. van der Heijde D, Kivitz A, Schiff MH, et al. Efficacy and safety of adalimumab in patients with ankylosing spondylitis: Results of a multicenter, randomized, double-blind, placebo-controlled trial. Arthritis Rheum 2006; 54: 2136-2146. 
15. Smolen J, Landewe RB, Mease P, et al. Efficacy and safety of certolizumab pegol plus methotrexate in active rheumatoid arthritis: The RAPID 2 study. A randomised controlled trial. Ann Rheum Dis 2009; 68: 797-804.

16. Keystone E, van der Heijde D, Mason D Jr, et al. Certolizumab pegol plus methotrexate is significantly more effective than placebo plus methotrexate in active rheumatoid arthritis: Findings of a fifty-two-week, phase III, multicenter, randomized, double-blind, placebo-controlled, parallel-group study. Arthritis Rheum 2008; 58: 3319-3329.

17. Fleischmann R, Vencovsky J, van Vollenhoven RF, et al. Efficacy and safety of certolizumab pegol monotherapy every 4 weeks in patients with rheumatoid arthritis failing previous disease-modifying antirheumatic therapy: The FAST4WARD study. Ann Rheum Dis 2009; 68: 805-811.

18. Wiland P, Świerkot J, Maśliński W. Certolizumab pegol w leczeniu reumatoidalnego zapalenia stawów. Reumatologia 2011; 49: 253-263.

19. Nesbitt A, Fossati G, Bergin M, et al. Mechanism of action of certolizumab pegol (CDP870): In vitro comparison with other anti-tumor necrosis factor alpha agents. Inflamm Bowel Dis 2007; 13: 1323-1332.

20. Tracey D, Klareskog L, Sasso EH, et al. Tumor necrosis factor antagonist mechanisms of action: A comprehensive review. Pharmacol Ther 2008; 117: 244-279.

21. Cimzia 200 mg solution for injection. [Internet].; 2012; cited 14 Dec 2012]. Available from: www.ema.europa.eu/docs/ en_GB/document_library/EPAR_Product_Information/human/001037/WC500069763.pdf.

22. Hwang WY, Foote J. Immunogenicity of engineered antibodies. Methods 2005; 36: 3-10.

23. Palframan R, Airey M, Moore A, et al. Use of biofluorescence imaging to compare the distribution of certolizumab pegol, adalimumab, and infliximab in the inflamed paws of mice with collagen-induced arthritis. J Immunol Methods 2009; 348: 36-41.

24. Landewe R, Braun J, Deodhar A, et al. Efficacy of certolizumab pegol on signs and symptoms of axial spondyloarthritis including ankylosing spondylitis: 24-week results of a double-blind randomised placebo-controlled phase 3 study. Ann Rheum Dis 2014; 73: 39-47.

25. Callhoff J, Sieper J, Weiß A, et al. Efficacy of TNF $\alpha$ blockers in patients with ankylosing spondylitis and non-radiographic axial spondyloarthritis: a meta-analysis. Ann Rheum Dis 2014 Apr 9 [in print]; doi: 10.1136/annrheumdis-2014-205322.

26. Mease PJ, Fleischmann R, Deodhar AA, et al. Effect of certolizumab pegol on signs and symptoms in patients with psoriatic arthritis: 24-week results of a phase 3 double-blind randomised placebo-controlled study (RAPID-PsA). Ann Rheum Dis 2014; 73: 48-55.

27. Taylor W, Gladman D, Helliwell P, et al. Classification criteria for psoriatic arthritis: Development of new criteria from a large international study. Arthritis Rheum 2006; 54: 2665 2673.

28. Sieper J, van der Heijde D, Dougados M, et al. Efficacy and safety of adalimumab in patients with non-radiographic axial spondyloarthritis: Results of a randomised placebo-controlled trial (ABILITY-1). Ann Rheum Dis 2013; 72: 815-822. 